\title{
2010s-03 \\ Loss of Substitutability: A Note On Disparity between WTP and WTA
}

\author{
Arnaud Z. Dragicevic
}

\begin{tabular}{c}
\hline Série Scientifique \\
Scientific Series
\end{tabular}

\section{Montréal}

Janvier 2010

(C) 2010 Arnaud Z. Dragicevic. Tous droits réservés. All rights reserved. Reproduction partielle permise avec citation du document source, incluant la notice $($ C.

Short sections may be quoted without explicit permission, if full credit, including (C) notice, is given to the source.
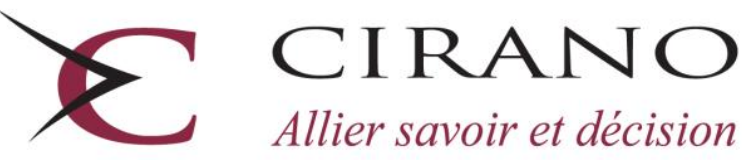

Allier savoir et décision

Centre interuniversitaire de recherche en analyse des organisations 


\section{CIRANO}

Le CIRANO est un organisme sans but lucratif constitué en vertu de la Loi des compagnies du Québec. Le financement de son infrastructure et de ses activités de recherche provient des cotisations de ses organisations-membres, d'une subvention d'infrastructure du Ministère du Développement économique et régional et de la Recherche, de même que des subventions et mandats obtenus par ses équipes de recherche.

CIRANO is a private non-profit organization incorporated under the Québec Companies Act. Its infrastructure and research activities are funded through fees paid by member organizations, an infrastructure grant from the Ministère du Développement économique et régional et de la Recherche, and grants and research mandates obtained by its research teams.

\section{Les partenaires du CIRANO}

Partenaire majeur

Ministère du Développement économique, de l'Innovation et de l'Exportation

\section{Partenaires corporatifs}

Banque de développement du Canada

Banque du Canada

Banque Laurentienne du Canada

Banque Nationale du Canada

Banque Royale du Canada

Banque Scotia

Bell Canada

BMO Groupe financier

Caisse de dépôt et placement du Québec

Fédération des caisses Desjardins du Québec

Financière Sun Life, Québec

Gaz Métro

Hydro-Québec

Industrie Canada

Investissements PSP

Ministère des Finances du Québec

Power Corporation du Canada

Raymond Chabot Grant Thornton

Rio Tinto

State Street Global Advisors

Transat A.T.

Ville de Montréal

\section{Partenaires universitaires}

École Polytechnique de Montréal

HEC Montréal

McGill University

Université Concordia

Université de Montréal

Université de Sherbrooke

Université du Québec

Université du Québec à Montréal

Université Laval

Le CIRANO collabore avec de nombreux centres et chaires de recherche universitaires dont on peut consulter la liste sur son site web.

Les cahiers de la série scientifique (CS) visent à rendre accessibles des résultats de recherche effectuée au CIRANO afin de susciter échanges et commentaires. Ces cahiers sont écrits dans le style des publications scientifiques. Les idées et les opinions émises sont sous l'unique responsabilité des auteurs et ne représentent pas nécessairement les positions du CIRANO ou de ses partenaires.

This paper presents research carried out at CIRANO and aims at encouraging discussion and comment. The observations and viewpoints expressed are the sole responsibility of the authors. They do not necessarily represent positions of CIRANO or its partners. 


\title{
Loss of Substitutability: A Note on Disparity between WTP and WTA*
}

\author{
Arnaud Z. Dragicevic ${ }^{\dagger}$
}

\begin{abstract}
Résumé / Abstract
Ce papier traite de la disparité entre les indices de consentement-à-payer et consentement-àrecevoir dans l'évaluation hors-marché. En raison de l'effet de substitution, les pertes sèches sont plus valorisées que les coûts d'opportunité. A l'égard des pertes sèches, nous montrons que la substituabilité imparfaite induit un consentement-à-recevoir respectivement infini et fini dans les modèles néoclassique et d'aversion aux pertes. Dès lors, la notion de perte sèche est différemment abordée dans les deux modèles.
\end{abstract}

Mots clés : Disparité CAP-CAR, effet de substitution, aversion aux pertes.

This paper focuses on the disparity between willingness-to-pay and willingness-to-accept in nonmarket valuation. We note that the substitution effect and the endowment effect, which are typically put forward to justify the disparity, do not consider the same question. We then propose a new model that combines both effects using reference-dependence. We show that compensation demanded for the loss of substitutability is unbounded in the neoclassical framework and bounded inside loss aversion. Our results suggest avenues for empirical test of a long-standing issue.

Keywords: WTP-WTA gap, substitutability, reference-dependence.

Codes JEL : D61, D81, Q51

\footnotetext{
*I would like to thank Dominique Bureau, Jim Engle-Warnick, Jason Shogren, Bernard Sinclair-Desgagné and Marc Willinger for their helpful comments. Also thanks to Anne Boring, Damien Bosc and Matias Nunez for our conversations. The usual disclaimer applies.

${ }^{\dagger}$ CIRANO and École Polytechnique ParisTech. CIRANO, 2020 rue University, Montréal (QC) H3A 2A5

Canada, arnaud.dragicevic@cirano.qc.ca.
} 


\section{INTRODUCTION}

Experiments have given evidence of large disparities between willingness-to-pay (WTP) and willingness-to-accept (WTA) and laboratory markets confirmed persistency in disparities (Knetsch and Sinden, 1984; Brookshire and Coursey, 1987; Shogren et al., 1994). To justify the persistence of the disparity, theorists invoke either the substitution effect (Hanemann, 1991) or the endowment effect (Kahneman and Tversky, 1979; Thaler, 1980). The effects work with changes in the qualities or changes in the fixed quantities of both public and private goods. The substitution effect results from the agent's imperfect trade-off between the goods. When a good has an imperfect substitute, the disparity between indices increases as the degree of substitution decreases (Shogren et al., 1994). The endowment effect makes agents value losses higher than equivalent gains. Morrison (1997) tries to reconcile the effects by combining them. Hanemann (1999) suggests that a quasi-concave utility function with inversely proportional disparity to the substitution effect can both explain the standard WTP and WTA disparity as well as the gain and loss disparity.

This paper considers the debate on substitutability between public and private goods (or income). We define the substitution effect as an opportunity loss and the endowment effect as a loss of substitutability. We make both effects depend on substitutability. This demarche unfolds an amalgam. Substitutability and loss aversion do not consider the same type of WTA. As we transpose them into a common setting of reference-dependence, we find that compensation demanded for the loss of substitutability is respectively unbounded in the neoclassical framework and bounded with loss aversion. The concepts of opportunity loss and loss of substitutability are introduced in Section 1. We show the properties of boundedness in Section 2. Concluding comments are given in Section 3. 


\section{OPPORTUNITY LOSS AND LOSS OF SUBSTITUTABILITY}

Given a preference $u(x, q)$ where $q$ and the $x$ 's - bought by the income $y$-represent the public and private goods (or income), $\mathrm{WTP}^{+}$for $q$ is defined as the maximum amount an agent is willing to pay to guarantee the improvement of the public goods' level from $q^{0}$ to $q^{1}\left(q^{0}<q^{1}\right)$; likewise, $\mathrm{WTA}^{+}$for $q$ is the minimum amount an agent is willing to receive to forego the improvement from $q^{1}$ to $q^{0}$. The symmetric reasoning is WTP $^{-}$to avoid the public goods' degradation and WTA $^{-}$to tolerate it. Combinations of the $x$ 's (via $y$ ) and $q$ along the indifference curves being imperfectly substitutable, agents display convex preferences and $\mathrm{WTP}^{+}<\mathrm{WTA}^{+}($Figure 1).

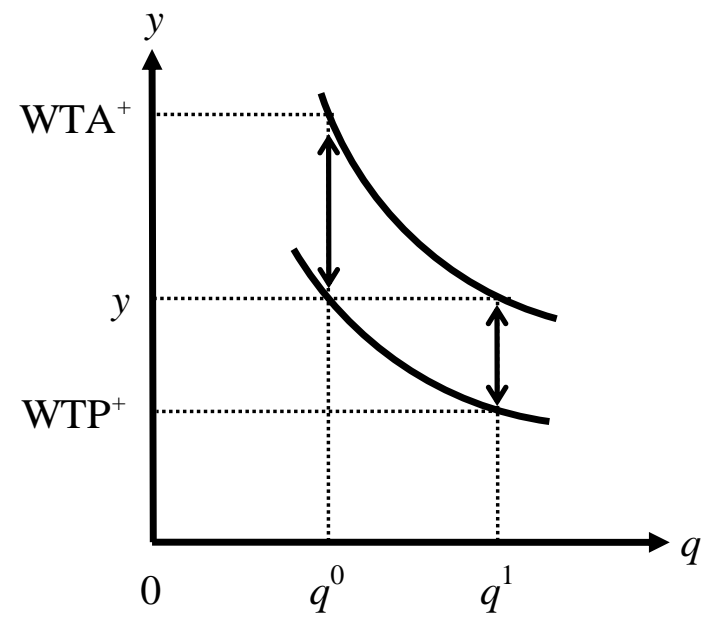

Fig. 1 Substitutability between $q$ and the $x$ 's

In the usual neoclassical framework, preferences are independent of initial endowments. That is why Hanemann (1991) points out that Kahneman and Tversky's (1979) loss aversion differs from Hicksian preferences (footnote 25). To address this issue, Bateman et al. (1997) incorporate reference points into the neoclassical framework. Their work permits identifying the equivalent gain $\left(\mathrm{WTA}^{+}\right)$, which is the minimum amount an agent is willing to receive to sacrifice a foregone 
gain $\left(q^{1} \equiv q^{0}+\Delta\right.$ where $\Delta>0$ is the change from the status quo level $\left.q^{0}\right)$ and the compensating loss $\left(\mathrm{WTA}^{-}\right)$, which is the minimum amount an agent is willing to receive to tolerate a net loss $\left(q^{1} \equiv q^{0}-\Delta\right)$. Unlike the standard disparity where the changes go in the same direction $(+\Delta$ or $-\Delta)$, the gain and loss disparity is the study of changes that depart in opposite directions $(+\Delta$ and $-\Delta$ ). An endowed agent introduces a reference point and shifts her position on the map, such that the shape of her indifference curve is altered. The income or wealth effect - the spacing between the indifference curves - does not count, for the gain and loss perspective involves a single curve observed from some positive or negative shift. Figure 2 illustrates the welfare indices observed from the reference point coordinates $\left(q^{0}, y\right)$ of the utility arguments. The grey curve depicts some pre-endowed utility in $q$ and the $x$ 's $($ via $y$ ). The inclusion of contextdependence changes the initial utility to either a gain in utility $(+\Delta)$ or a loss in utility $(-\Delta)$.

In the behavioral framework of loss aversion, Tversky and Kahneman (1991) introduce a value function where agents have different preferences over gains and losses relative to their status quo. Figure 3 illustrates welfare measures from the loss aversion perspective. The reference point coordinates $\left(r_{q}, r_{x}\right)$ stand for the initial use of public goods $q$ and the initial consumption of private goods $x$ (via $y$ ). Their model explains the source of the gain and loss disparity. Although the authors assert that the disparity between willingness-to-pay and willingness-to-accept is an implication of loss aversion, what they really compare is $\mathrm{WTP}^{+}$with $\mathrm{WTA}^{-}$. For that reason, their design cannot interpret the notion of foregone gain, nor can explain the suggested disparity between $\mathrm{WTP}^{+}$and $\mathrm{WTA}^{+}$. 


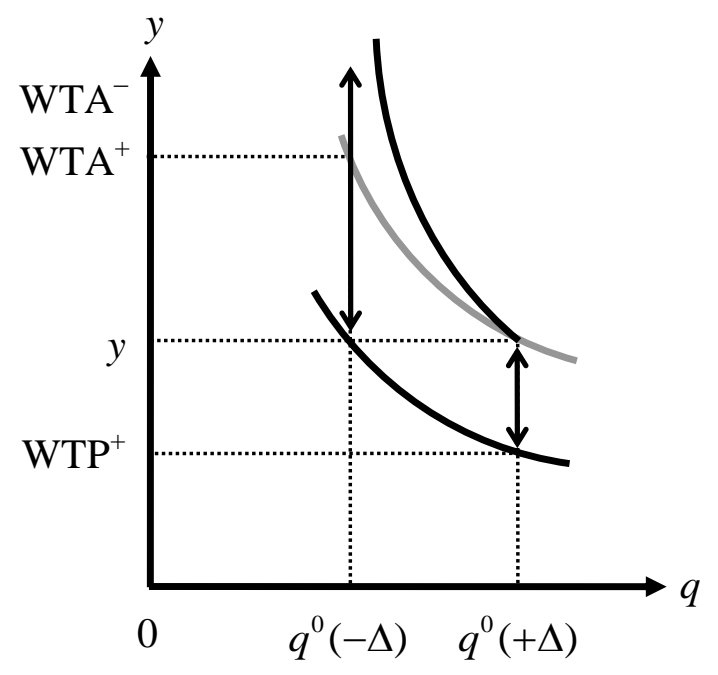

Fig. 2 Reference-dependent preferences

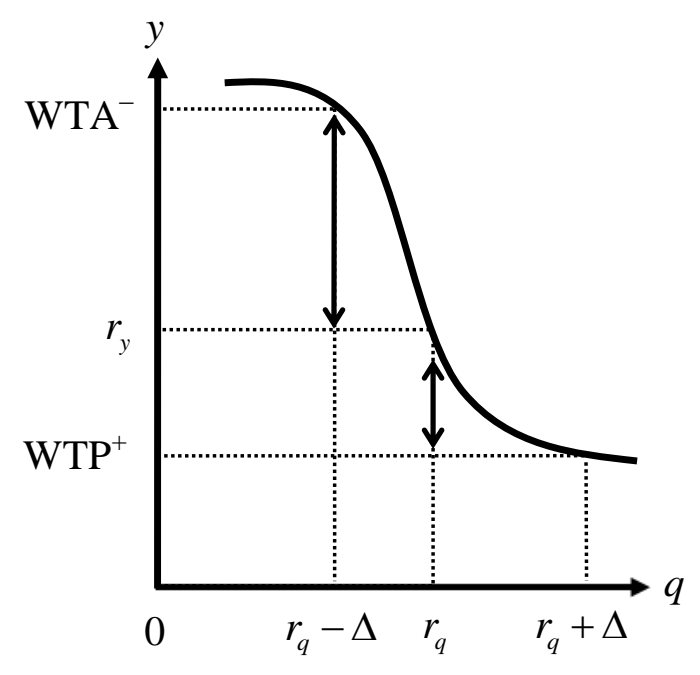

Fig. 3 Welfare measures in loss aversion

Consider the concept of opportunity loss (i.e. foregone gain) to improve the level of public goods as an opportunity cost of an interest in a bank account. By means of convexity, the substitution effect reveals, in the neoclassical framework, the opportunity loss exclusively; the lower the substitutability, the higher the opportunity loss. But the utility of the agent does not change. At worst, she faces the status quo. This brings us to the first definition. ${ }^{1}$

DEFINITION 1. Imperfect substitutability, which implies a convex-shaped indifference curve, is an opportunity loss between the public and private goods (or income).

When the agent values a true loss and weights it against an equivalent gain, the loss in consideration is a net loss. The net loss is a critical change, for agents take account of the goods they can no longer substitute; they explicitly value this loss of substitutability by shifting preferences, which makes them switch to a steeper indifference curve. The lower the ex ante substitutability between the public and private goods (or income), the higher the slope of both the

\footnotetext{
${ }^{1}$ In loss aversion, the isolated consideration of the nonlinear value curve reveals the opportunity loss.
} 
initial and shifted indifference curves. In Tversky and Kahneman's model, this pertains to the loss aversion segment of the value curve. In order to make a comparison between the models, one must introduce reference-dependence. The second definition comes out.

DEFINITION 2. The shift in preferences, caused by the presence of reference-dependence, expresses a loss of substitutability between the goods.

\section{LOSS OF SUBSTITUTABILITY AND BOUNDEDNESS}

Randall and Stoll (1980) demonstrate that the standard disparity is bounded by the ratio between the price flexibility of income and endowment. Cook and Graham (1977) assert that compensation demanded for irreplaceable commodities, which we assume to be imperfectly substitutable, depends on the initial level of wealth or endowment. As the probability of loss approaches certainty, $\mathrm{WTA}^{-}$tends to infinity. Amiran and Hagen (2003) suggest that the high level of wealth produces an infinite $\mathrm{WTA}^{+}$for irreversible losses of public goods $\left(\mathrm{WTA}^{-} d e\right.$ facto) when the utility function is asymptomatically bounded. They show that the income elasticity of the inverse compensated demand is bounded above and below by positive values independent of the public goods' amount. Even if the substitution effect plays a key role, for it induces frictional trade-offs between the public and private goods (or income), their referenceindependent model can only speak for opportunity losses, but surely not for net losses.

In the neoclassical framework with reference-dependent preferences, we claim that the loss of substitutability, which induces the shifting on the map, implicates unbounded compensation demanded $\left(\mathrm{WTA}^{-} \rightarrow \infty\right)$. In order to prove our claim, we replace the nonsatiation assumption by the following assumption of preferences over reference points. 
ASSUMPTION. For any level of income $y$ that buys the $x$ 's, the status quo $r_{q}$ is strictly preferred to the net loss of public goods $r_{q}-\Delta \geq q^{0}$ where $\Delta>0$. Formally, the assumption verifies the following strict inequality

$$
u\left(r_{q}-\Delta, y\right)<u\left(r_{q}, y\right)
$$

Figure 4 shows that the argument of substitutability intervenes twice. Outcome (1) lies in the convexity of curvature of the initial grey indifference curve, for the slope increases with opportunity losses. Outcome (2) results from the loss of substitutability, yielding a shift to an updated utility curve asymptotic at $q^{0}$.

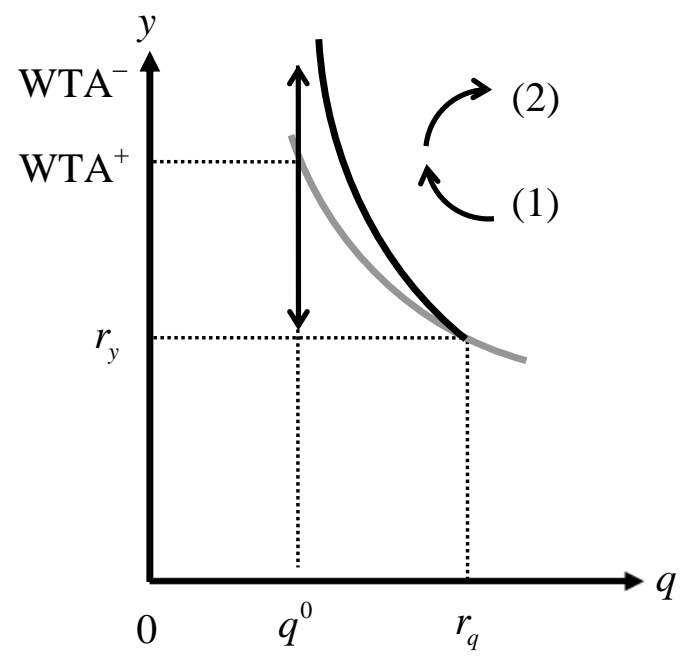

Fig. 4 Unbounded compensation demanded

The combination of two yields an unbounded level of compensation $s$ unable to offset the loss of substitutability. Algebraically, we have

$$
u\left(r_{q}, y\right)>z\left(r_{q}-\Delta\right)+s>u\left(q^{0}, y\right)
$$


Proposition 1. Within the neoclassical framework with reference-dependence, the loss of substitutability between the imperfectly substitutable public and private goods (or income) induces unbounded compensation demanded.

PROOF IN THE APPENDIX.

The limit of $\mathrm{WTA}^{-}$is due to the pivoting of the convex indifference curve. ${ }^{2}$ Contrary to Cook and Graham (1977) and similarly to Amiran and Hagen (2003), our curve is asymptotic at critical levels of losses around $q^{0}$.

Despite the preceding models which consider substitutability as the mainspring for infinite numéraire compensation, our design neither depends on the initial level of wealth, nor the initial endowment in market goods, nor on the boundedness of the utility function. It simply depends on the opportunity loss when goods are imperfectly substitutable and on the loss of opportunity to substitute between the goods.

The same rationale of context-dependence within loss aversion produces a different result. The agent substitutes the loss of public goods with monetary compensation above the kink point; below is the opposite. At the kink point coordinates $\left(r_{q}, r_{y}\right)$ the agent is equidistant to both references points and perfectly indifferent between the public and private goods (or income). Any other point along the nonlinear curve exhibits some opportunity loss. The loss of substitutability, expressed in terms of compensation demanded, is captured by the segment above the kink point. From Figure 3, we see that the marginal valuation exhibits a diminishing sensitivity in loss aversion. We have

\footnotetext{
${ }^{2}$ Although this result is comparable to that of Morrison (1997), we consider the loss of substitutability rather than the endowment effect and focus on the properties of boundedness.
} 


$$
\left(r_{q}-\Delta-r_{q}\right) \partial v / \partial r_{q} \leq 0 \text { as } r_{q}-\Delta<r_{q}
$$

When $r_{q}-\Delta$ goes further from $r_{q}$, additional reductions in $q$ lead to smaller changes in the value of the value function. In other terms, the diminishing sensitivity implies a diminishing effect of the loss of substitutability. In opposition to the increasing slope for greater losses in the neoclassical framework, the loss in value of the value function from the public goods' downgrading decreases as the agent moves away from the reference point; this implies a bounded $\mathrm{WTA}^{-}$value for the loss of substitutability.

PROPOSITION 2. Given the constant diminishing sensitivity with loss aversion, compensation demanded for the loss of substitutability between the imperfectly substitutable public and private goods (or income) is bounded.

\section{PROOF IN THE APPENDIX.}

There is a difference between the neoclassical framework and loss aversion in the formal representation of loss of substitutability. If we superpose the segments illustrating $\mathrm{WTA}^{-}$, their respective curvatures reveal two types of behavior (Figure 5). Endowed neoclassical agents represented by the grey segment manifest an increasing marginal disutility as $\left(r_{q}-\Delta\right) \rightarrow q^{0}$. Inside loss aversion represented by the black segment, agents exhibit high loss aversion with small losses, but they turn out to be less sensitive with greater losses, for marginal valuation is subjected to diminishing sensitivity. The further something moves from a reference point, the less additional changes matter, which here means limited frictions in the loss of trade-off. Loss averse agents end up asking for bounded compensation. 


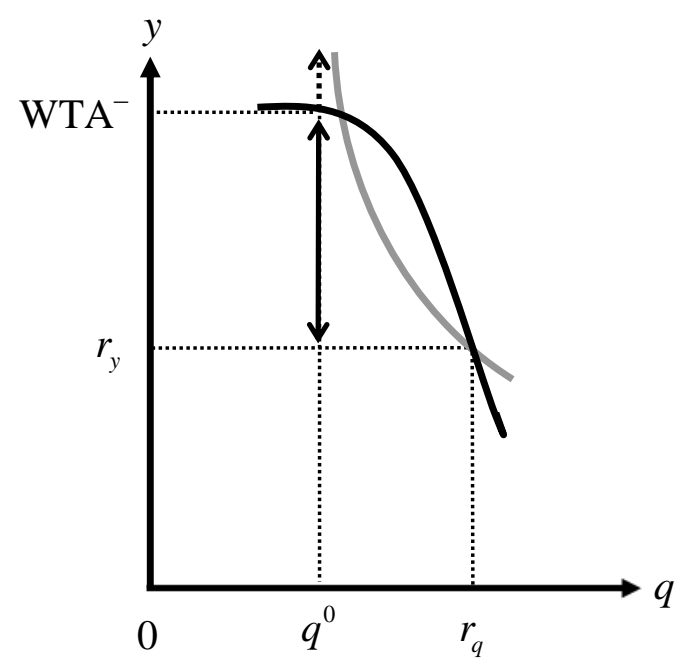

Fig. 5 Loss of substitutability

The implications of our results are new. In case of loss of substitutability between the public and private goods (or income) - commodities that we know to be imperfectly substitutable or inclined to the effect of opportunity loss - endowed neoclassical agents demand unbounded compensation, whereas loss averse agents ask for bounded compensation. This works as an anchoring effect or the retention of the status quo and occurs because neither adapt their reference points. While psychologists consider loss aversion to invalidate agents' rational preferences, we see that past some level of changes in the public goods' level, the perceptual sensitivity of loss of substitutability limits their proclivity toward exaggerated valuation of losses.

\section{CONCLUSIONS}

The concept of opportunity loss clarifies the standard disparity from Hanemann's analysis. In case the scenario is a true loss instead of a foregone gain, the opportunity loss becomes a loss of substitutability, enlarging the initial disparity, for agents heavily value things they cannot substitute any longer. Experimental findings from Boyce et al. (1992) and Chapman (1998) support this claim. Like in Hanemann (1991) and Amiran and Hagen (2003) our results show that 
the unbounded compensation demanded arises from the impossibility to substitute public with private goods (or income). However, the results clarify the real stake of the nature of welfare measures, without making functional restrictions. At last, we observe that loss aversion produces bounded compensation demanded. This proposition should be tested in a laboratory. Whether agents have unbounded or bounded values for the public goods' losses could answer the longstanding question of which model best values the preferences over public goods.

\section{APPENDIX}

\section{Proof of Proposition 1.}

For $q^{0} \leq r_{q}-\Delta<r_{q}$ with $\Delta>0$, we have $u_{0}=u\left(r_{q}, y\right)$ and $u^{-}(q, y)=u\left(q^{0}, y\right)$. Let us set $z(q) \equiv \sup \left[u\left(q^{0}, y\right)=u\left(r_{q}, y\right) \mid y \in \mathbf{R}_{+}\right]$for a level of monetary compensation such that the utility remains constant. For each $q \geq 0$ we have $z(q) \geq u(q, y)$. The supremum $z(q)$ is increasing in $q$. This says that for each level of income $y$ and for $r_{q}>q^{0}$ we have $u\left(r_{q}, y\right)>u\left(r_{q}-\Delta, y\right)$ because the status quo is always preferred to the net loss of the public good $\Delta$.

Let us set $z\left(r_{q}\right)-z\left(r_{q}-\Delta\right)=s$ where $s$ corresponds to WTA ${ }^{-}$. With $z\left(r_{q}\right)$ being the supremum for $u\left(r_{q}, y\right)$ and $z\left(r_{q}-\Delta\right)$ being the supremum for $u\left(r_{q}-\Delta, y\right)$ is there $y$ that gives $u\left(q^{0}, y\right)>z\left(r_{q}-\Delta\right)$ or $u\left(r_{q}, y\right)>z\left(r_{q}-\Delta\right)+s ?$

We know that $q^{0} \leq r_{q}-\Delta<r_{q}$ so for all $y$ we have $z\left(q^{0}\right)<z\left(r_{q}\right)$ and $z\left(q^{0}\right) \leq z\left(r_{q}-\Delta\right)$. By definition we know that $z\left(r_{q}-\Delta\right)+s=z\left(r_{q}\right)$ such that $z\left(q^{0}\right)+s \leq z\left(r_{q}\right)$ holds. Moreover, $z\left(q^{0}\right) \geq u\left(q^{0}, y\right)$ because $z(q) \geq u(q, y)$ thus $z\left(q^{0}\right)+s>u\left(q^{0}, y\right)$ or $z\left(r_{q}-\Delta\right)+s>u\left(q^{0}, y\right)$. As 
$r_{q}>q^{0}$ we have $z\left(r_{q}-\Delta\right)>z\left(q^{0}\right)$ or $z\left(r_{q}\right)-s>z\left(q^{0}\right)$ hence $u\left(r_{q}, y\right)>z\left(q^{0}\right)+s$. We conclude that $u\left(q^{0}, y\right)<z\left(r_{q}-\Delta\right)+s<u\left(r_{q}, y\right)$.

\section{Proof of Proposition 2.}

For all $\left(r_{q}-\Delta\right) \in\left(0, r_{q}\right]$ and $v$ a value function defined on $\mathbf{R}_{+}^{*}$ with $\left(0, r_{q}\right]$. The shape of losses is represented in a positive space because we work with positive monetary compensations; $v$ is nonincreasing and concave. We have $v\left(r_{q}-\Delta\right) \leq v\left(r_{q}\right)+v^{\prime}\left(r_{q}\right)\left(r_{q}-\Delta-r_{q}\right)$. The right-hand expression of the inequality is the tangent of $v$ at $r_{q}$. It gives $v\left(r_{q}-\Delta\right) \leq v\left(r_{q}\right)+v^{\prime}\left(r_{q}\right)\left(-r_{q}\right)$ when $r_{q}-\Delta=0$ which is independent of $r_{q}-\Delta$. The value function is bounded.

\section{REFERENCES}

Amiran, E.Y. and Hagen, D.A. (2003). 'Willingness To Pay and Willingness To Accept: How Much Can They Differ? Comment', American Economic Review, vol. 93(1), pp. 458-63.

Bateman, I., Munro, A., Rhodes, B., Starmer, C. and Sugden, R. (1997). 'A Test of the Theory of Reference-Dependent Preferences', Quarterly Journal of Economics, vol. 112(2), pp. 479-05.

Boyce, R.R., Brown, T.C., McClelland, G.H., Peterson, G.L. and Schulze, W.D. (1992). 'An Experimental Examination of Intrinsic Values as a Source of the WTA-WTP Disparity', American Economic Review, vol. 82(5), pp. 1366-73. 
Brookshire, D.S. and Coursey, D.L. (1987). 'Measuring the Value of a Public Good: An Empirical Comparison of Elicitation Procedures', American Economic Review, vol. 77(4), pp. 554-66.

Cook, P.J. and Graham, D.A. (1977). 'The Demand for Insurance and Protection: The Case of Irreplaceable Commodities', Quarterly Journal of Economics, vol. 91(1), pp. 143-56.

Chapman, G.B. (1998). 'Similarity and Reluctance to Trade', Journal of Behavioral Decision Making, vol. 11(1), pp. 47-58.

Hanemann, W.M. (1991). 'Willingness to Pay and Willingness to Accept: How Much Can they Differ?', American Economic Review, vol. 81(3), pp. 635-47.

Hanemann, W.M. (1999). 'The Economic Theory of WTP and WTA', in (I.J. Bateman and K.G. Willis, eds.), Valuing the Environmental Preferences: Theory and Practice of the Contingent Valuation Method in the US, EC and Developing Countries, pp. 42-95, Oxford University Press.

Kahneman, D. and Tversky, A. (1979). 'Prospect Theory: An Analysis of Decisions Under Risk', Econometrica, vol. 47(2), pp. 263-91.

Knetsch, J.L. and Sinden, J.A. (1984). 'Willingness to Pay and Compensation Demanded: Experimental Evidence of an Unexpected Disparity in Measures of Value', Quarterly Journal of Economics, vol. 99(3), pp. 507-21. 
Morrisson, G.C. (1997). 'Resolving Differences in Willingness to Pay and Willingness to Accept: Comment', American Economic Review, vol. 87(1), pp. 236-40.

Randall, A. and Stoll, J.R. (1980). 'Consumer's Surplus in Commodity Space', American Economic Review, vol. 70(3), 449-55.

Shogren, J.F., Shin, S.Y., Hayes, D.J. and Kliebenstein, J.B. (1994). 'Resolving Differences in Willingness to Pay and Willingness to Accept', American Economic Review, vol. 84(1), pp. 25570.

Thaler, R. (1980). 'Toward a Positive Theory of Consumer Choice', Journal of Economic Behavior and Organization, vol. 1, pp. 39-60.

Tversky, A. and Kahneman, D. (1991). 'Loss Aversion in Riskless Choice: A ReferenceDependent Model', Quarterly Journal of Economics, vol. 106(4), pp. 1039-61. 